Eduvest - Journal of Universal Studies

Volume 1 Number 11, November 2021

p- ISSN 2775-3735 e-ISSN 2775-3727

\title{
THE EFFECT OF HR COMPETENCE, IEP INNOVATION AND SERVICE QUALITY ON PROJECT MANAGEMENT IN BUILDING PROJECT PERFORMANCE
}

Tiara Ardhiti Estungkorodewi, Mombang Sihite and Derriawan

Pancasila University, Indonesia

E-mail: tiaraardhiti@gmail.com,mombangsihite@univpancasila.ac.id dan

derriawan@univpancasila.ac.id

\begin{tabular}{|c|c|}
\hline ARTIC & 3STRACT \\
\hline $\begin{array}{l}\text { Received: } \\
\text { October, } 26^{\text {th }} \\
2021 \\
\text { Revised: } \\
\text { November, } 16^{\text {th }} \\
2021 \\
\text { Approved: } \\
\text { November, } 18^{\text {th }} \\
2021\end{array}$ & $\begin{array}{l}\text { The use of Integrated Engineering Procurement (IEP) } \\
\text { information technology can allegedly be used to build HR } \\
\text { competencies, service quality, project performance and } \\
\text { project management to overcome problems of project } \\
\text { time delays, costs, and quality/quality of work. The } \\
\text { purpose of this study is to identify the effect of HR } \\
\text { competence, IEP innovation (integrated engineering } \\
\text { procurement), service quality on project management in } \\
\text { improving project performance. This research uses a case } \\
\text { study in the Situ Bagendit revitalization project run by PT } \\
\text { Adhi Karya Tbk. The research method used is quantitative. } \\
\text { Quantitative research using SEM PLS. Sampling through } \\
\text { purposive sampling method and obtained } 117 \text { research } \\
\text { units. The results showed that based on SEM analysis } \\
\text { stated that the relationship between HR Competence, IEP } \\
\text { Innovation and Service Quality was significantly related to } \\
\text { project performance. Likewise, the relationship between } \\
\text { Project Management and project performance has } \\
\text { created a significant positive. }\end{array}$ \\
\hline $\mathrm{KEY}$ & $\begin{array}{l}\text { HR Competence, IEP Innovation, Service Quality, Project } \\
\text { Management, Project Performance }\end{array}$ \\
\hline C) (†) & $\begin{array}{l}\text { This work is licensed under a Creative Comr } \\
\text { Attribution-ShareAlike } 4.0 \text { International }\end{array}$ \\
\hline
\end{tabular}

Tiara Ardhiti Estungkorodewi, Mombang Sihite and Derriawan. (2021). The Effect of HR Competence, IEP Innovation and Service Quality on Project Management in Building Project Performance. Journal Eduvest.

How to cite:

E-ISSN:

1(11): 1240-1252

Published by: 


\section{INTRODUCTION}

National strategy project is an infrastructure development project that is considered strategic enough to optimize the economic sector, equitable development, improve community welfare, as well as development in each region (Siswanto \& Alfian, 2016). This design has the intention of meeting all basic needs, as well as optimizing the prosperity of the community. In the National Medium-Term Development Plan or abbreviated as RPJMN 2020-2024, the government prioritizes private investors with an allocation of $42 \%$. Thus, infrastructure development capital relies on the state budget.

Infrastructure is a physical facility that plays a crucial role and becomes the foundation and wheel that drives economic growth. Infrastructure, as community social capital, is quite needed to accelerate national development and function as a catalyst for the production and marketing stages (Naleng \& Monintja, 2020). According to the conditions on the ground, the implementation of infrastructure projects has an impact on the quality of the built infrastructure. Damage to various government buildings that were not long ago often occurred, the results of the work did not match the specifications, the service life of the building ended quickly, and the construction of the building failed. The poor infrastructure situation also has a negative impact on social and economic development. There are various technical and non-technical factors that are directly or indirectly involved in influencing the quality of infrastructure (Adyatma \& Oktaviani, 2015).

The stalled national projects that have been in existence include the construction of the Pemalang-Semarang toll road, the construction of the Red and White Bridge in Ambon, the construction of Kertajati Airport in Majalengka, Wisma Atlet Hambalang, 34 power plant construction projects, the Umbulan minimal water supply system project in Pasuruan, and many other projects. others were neglected, especially in 2020-2021 to coincide with the COVID 19 pandemic. Construction services as explained in Law Number 18 of 1999 are consulting services for construction work plans, work implementation, and construction services, including supervision of construction work (Raharja, 2014). Construction work itself is a series of works through the design of plans and implementation, including monitoring which includes architectural, civil, mechanical, electrical, and environmental management works, as well as equipment to realize its physical form. Several stages in a construction project, including feasibility studies, briefing, design, procurement, construction, and maintenance and start-up (Noferi \& Wibowo, 2017).

The Directorate General of Resources and Equipment of Post and Information Technology (Ditjen SDPPI) of the Ministry of Communication and Informatics has a plan by providing telecommunication statistical data and information in real time, so that it can be accessed directly for the benefit of business people, authority makers, or for the community (Setiawan, 2017). This will happen because of technological advances in the field of data analysis. With technological advances that are increasingly driving the industrial revolution 4.0, there will be disruptions or disruptions that will affect the company. Disruption comes from deception or like the non-acceptance of denial. The more disrupted it gets, the more exciting it becomes and a network of new, invisible opponents becomes. Disruption strategy to generate new job opportunities, as well as competition that is only built through the latest procedures as well. Rhenald Khasali said that there are several designs that companies can implement in order to gain victory during competition, especially those that are increasingly stringent, firstly carrying out self-disruption through revolutionary observation of work procedures, innovating products, as well as designing online systems to integrate the company with the target 
market, as well as evaluating the funding structure. or business stage. The second stage is collaborating with new businesses that are developing or appear to be increasing in the market. Please look for similar work patterns in order to cut your budget. The third stage, which is to provide training for all executive ranks to examine the meaning of disruption and break their mindset. The final stage, which is to refocus the segment, examine the segments that have the opportunity to be opened and created without taking a long time (Kurniawan \& Budhi, 2017).

Problems with procurement or procurement in a construction project are the unavailability of updated material reports, material in and out information is not well documented, cost control is difficult to evaluate materials, the process of bookkeeping for warehouse card reports is still conventional, there is no standardization of project material reports, there is no material reporting digitally via smartphone.

According to the explanation in the background of the problem, if there is a main problem in the the field of procurement of construction projects is the unavailability of updated material reports, information in and out of materials is not well documented, Cost Control is difficult to evaluate materials, the process of accounting for warehouse card reports is still conventional, there is no standardization of project material reports, there is no material reporting digitally via smartphones. The purpose of this study is to analyze HR competencies that affect project management.

\section{RESEARCH METHOD}

The author uses a quantitative descriptive method. A method that mixes descriptive, qualitative, and quantitative methods. Descriptive research is research that tries to describe problems based on data collection, as well as analyzing and interpreting (Fitrah, 2018). While quantitative analysis using Structural Equotion Modeling (SEM). SEM is a multivariate statistical analysis method (Fernandes, 2017). SEM has 3 activities simultaneously. These activities include checking the validity and reliability of the instrument (confirmatory factor analysis), testing the relationship model between variables (path analysis), and obtaining a suitable model for prediction (structural model analysis and regression analysis). To process SEM data more easily, you can use the help of Smart PLS statistical software.

\section{RESULT AND DISCUSSION}

The Company has taken a lot of effort in managing the impact caused by changes both inside and outside the Company, with the aim of ADHI continuing to operate in the face of the dynamics of the times, technological advances along with increasing awareness of quality services. In Change Management, the following steps have been explained to be carried out by the Company.

1. Identification, namely the search or recognition of the following changes with the needs and types of changes.

2. Planning, namely technical analysis and determination of strategy, selection of supporting factors in order to create better changes.

3. Implementation, namely monitoring any changes and the possibility of other problems arising.

4. Evaluation and feedback, namely data collection and evaluation in order to have an impact on any changes. Details of the change plan (change management) in the business mechanism are described in each Department Manual. 
The Situ Bagendit area arrangement has the following scope of work:

1. Zone 1 Konstruksi Construction Area Work

a) Entrance gate and parking lot area work

b) Plaza area work

c) Tourist dock work

d) Amphitheater building works

e) Lotus garden work

f) Office building work

g) Service building work

h) Renovation work of kiosk building in main plaza

i) Control tower building works ( 3 units)

j) Food court building work

k) Work on building a waste disposal site (TPS)/garbage bin

1) Male/female toilet renovation work

m) City park area work/education zone

n) Outdoor \& landscaping installation

o) Bamboo mosque building

p) VIP Restaurant \& Pedestrian Building Type C

2. Pedestrian Work Zone 2-6

a) Pedestrian Work Zone 2 (Length 2,869.80 m')

b) Pedestrian Works Zone 3 (Length 1,157.90 m')

c) Pedestrian Work Zone 2 (809.20 m')

d) Pedestrian Works Zone 2 (Length $852.40 \mathrm{~m}^{\prime}$ )

e) Pedestrian Work Zone 2 (Length 1,006.20 m')

3. Construction of Nusa Kelapa Island Area

a) Nusa Kelapa Island Area Works, Land works, main plaza and secondary skin mosque area, pier 2 plaza, water plaza, floating bridge plaza, pier 3 plaza, playground plaza, literacy plaza, pedestrian, sky bridge, culinary shelter, floating bridge, outdoor furniture, pier 1, pier 2, mechanical \& plumbing clean water site, electrical site.

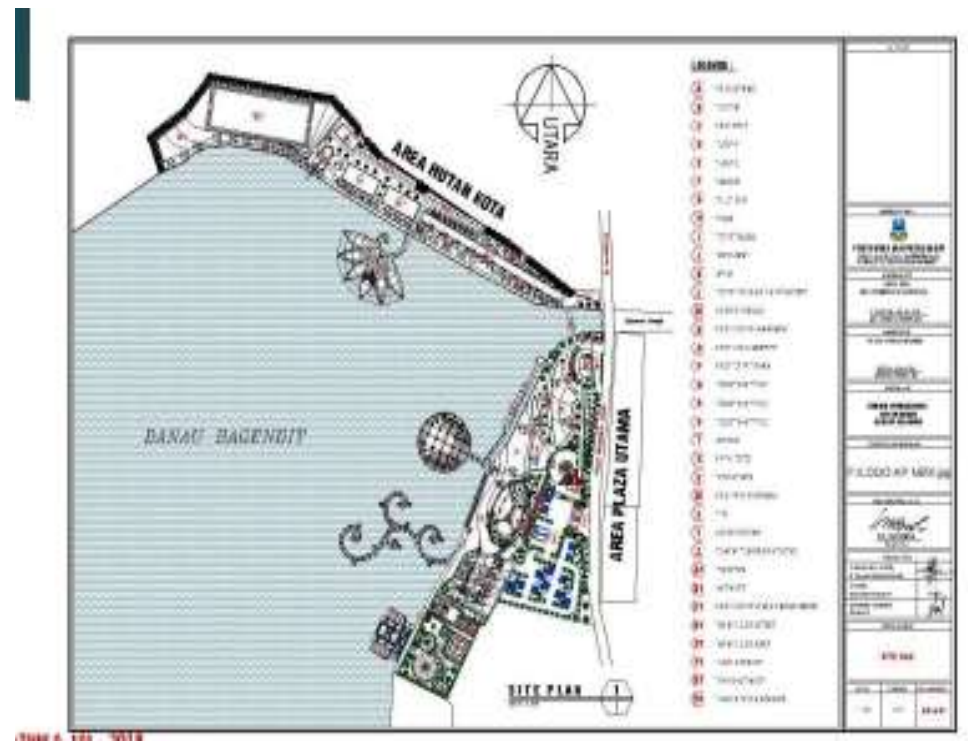

b) Mosque Construction Work Mosque Tower Work Figure 1. Site Plan Situ Bagendit 


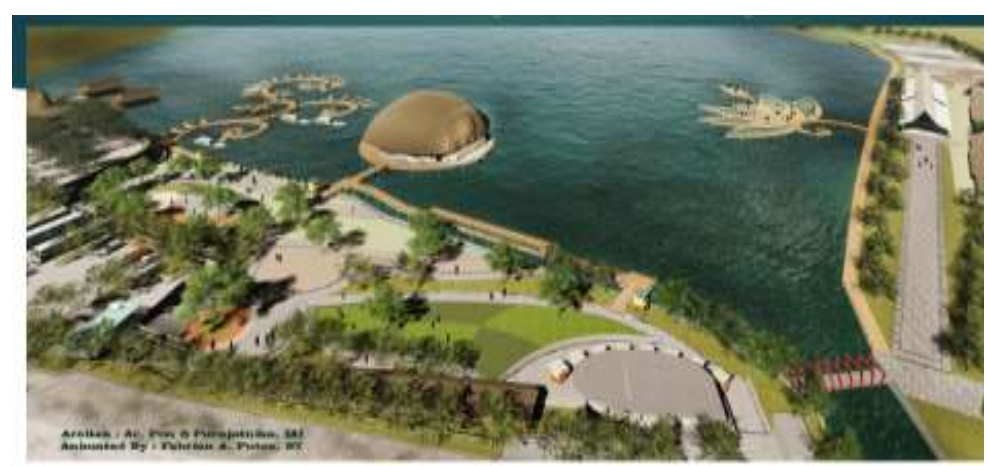

Figure 2. Site Plan 3D Situ Bagendit

The revitalization or arrangement of the tourist area Situ Bagendit in Bagendit Village, Banyuresmi District, Garut Regency, officially began on November 1, 2020. This was marked by the signing of a contract agreement between the Commitment Making Officer for the Development of Regional Settlement Areas II, the West Java (Jabar) Regional Settlement Infrastructure Center and PT Adhi Karya (Persero) Tbk. as the implementing contractor for the arrangement of the Situ Bagendit area.

\section{Construct Validity and Reliability Testing}

PLS analysis must be used in measuring each construct's validity and reliability as well as testing the Goodness of Fit in the outer model. The three methods for measuring it are as follows. First, convergent validity, second discriminant validity, and third, composite reliability.

a. Convergent Validity

In measuring the convergent validity of the outer model, namely through attention to each value of the outer loading of each variable. If the outer loading value is more than 0.5 , then the indicator is considered valid as convergent. The following is a table with a complete description of the results of the test:

Table 1. Convergent Validity Test Results.

\begin{tabular}{|c|c|c|c|}
\hline Variable & Indicator & Outer Loading & Information \\
\hline \multirow{5}{*}{ HR Competency } & KS1 & 0.864 & Valid \\
\hline & KS2 & 0.845 & Valid \\
\hline & KS3 & 0.894 & Valid \\
\hline & KS4 & 0.909 & Valid \\
\hline & KS5 & 0.833 & Valid \\
\hline \multirow{5}{*}{ Iep Innovation } & IIEP1 & 0.872 & Valid \\
\hline & IIEP2 & 0.901 & Valid \\
\hline & IIEP3 & 0.852 & Valid \\
\hline & IIEP4 & 0.745 & Valid \\
\hline & IIEP5 & 0.813 & Valid \\
\hline \multirow{5}{*}{ Service Quality } & KP1 & 0.825 & Valid \\
\hline & KP2 & 0.823 & Valid \\
\hline & KP3 & 0.789 & Valid \\
\hline & KP4 & 0.850 & Valid \\
\hline & KP5 & 0.731 & Valid \\
\hline
\end{tabular}




\begin{tabular}{cccc} 
& KP6 & 0.887 & Valid \\
\cline { 2 - 4 } & KP7 & 0.762 & Valid \\
\cline { 2 - 4 } & KP8 & 0.900 & Valid \\
\hline \multirow{3}{*}{ Project Management } & MP1 & 0.924 & Valid \\
\cline { 2 - 4 } & MP2 & 0.758 & Valid \\
\cline { 2 - 4 } & MP3 & 0.858 & Valid \\
\cline { 2 - 4 } Project Performance & MP4 & 0.899 & Valid \\
\hline & KJ1 & 0.856 & Valid \\
\cline { 2 - 4 } & KJ2 & 0.903 & Valid \\
\cline { 2 - 4 } & KJ3 & 0.835 & Valid \\
\cline { 2 - 4 } & KJ4 & 0.653 & Valid \\
\cline { 2 - 4 } & KJ5 & 0.846 & Valid \\
\hline
\end{tabular}

Source: Primary data processed, 2021

Based on these data, it appears that the value of the outer loading on the measurement of the research variables is more than 0.5 , thus each indicator is fulfilled as the fifth construct measuring instrument with convergent validity.

b. Discriminant Validity

In an effort to measure construct validity, one of them is by using discriminant validity. The discriminant validity is testing the construct as accurately as possible because it only measures the related construct, not other constructs. The mechanism used in measuring discriminant validity is through the AVE root method compared to the correlation between latent variables. When you see the root of AVE is greater than the correlation between latent variables, it indicates a valid discriminant. The following are the results of the Discriminant validity test with the AVE root:

Table 2. Discriminant Validity Test Results

\begin{tabular}{ccccccccc}
\hline \multirow{2}{*}{ Variable } & \multirow{2}{*}{ AVE } & \multirow{2}{*}{ Root } & \multicolumn{4}{c}{ Correlation Score Between Latent } & \multirow{2}{*}{ Information } \\
\cline { 5 - 8 } & & AVE & KS & IIEP & KP & MP & KJ & \\
\hline KK & 0.743 & 0.862 & & 0.794 & 0.813 & 0.742 & 0.716 & Valid \\
\hline KO & 0.756 & 0.869 & 0.794 & & 0.742 & 0.740 & 0.719 & Valid \\
\hline LK & 0.677 & 0.823 & 0.813 & 0.742 & & 0.714 & 0.729 & Valid \\
\hline PP & 0.703 & 0.838 & 0.742 & 0.740 & 0.714 & & 0.468 & Valid \\
\hline SK & 0.677 & 0.823 & 0.716 & 0.719 & 0.729 & 0.468 & & Valid \\
\hline
\end{tabular}

Source: Primary data processed, 2021

Through these data, the root value of the AVE appears to be greater than the correlation value between latent variables, so that the discriminant validity test has been fulfilled.

c. Composite Reliability

In measuring the reliability of the construct is to use composite reliability. Constructively, a variable can be considered reliable if the composite reliability value is more than 0.7 . The data from the reliability measurement results are presented in the table below: 
Table 3. Composite Reliability Test Results.

\begin{tabular}{ccc}
\hline Variable & Composite Reliability & Information \\
\hline Project Management & 0.920 & Reliable \\
\hline HR Competency & 0.939 & Reliable \\
\hline Iep Innovation & 0.943 & Reliable \\
\hline Service Quality & 0.922 & Reliable \\
\hline Project Performance & 0.912 & Reliable \\
\hline
\end{tabular}

Source: Primary data processed, 2021

Based on these data, it appears that all values of composite reliability show that it is 0.7 greater than the value, for that composite reliability is fulfilled. It can be concluded that each indicator is a measuring tool for each construct.

\section{Outer Model Results}

The outer model is a search for the size of the variable seen from every indicator in it. The outer loading and outer weight values show that each indicator weight becomes a measuring tool for each latent variable (Reagan, 2016). The largest indicator through outer loading and outer weight shows that the indicator is the most dominant or strongest measuring instrument. Then the outer loading can be considered to have significance in finding the size of the latent variable, if the T-statistic is greater than 1.96 and the P-value is less than 0.05 .

1. Outer Model on HR Competency Variables

HR competence is the first variable that there are five in determining the measurement. The results of the outer Market Orientation model are presented in the table below.

Table 4. Outer Model Results on Market Orientation Variables

\begin{tabular}{ccccc}
\hline Indicator & $\begin{array}{c}\text { Outer } \\
\text { Loading }\end{array}$ & T-statistic & P-value & Informatiom \\
\hline KS1 & 0.864 & 25.240 & 0.000 & significant \\
\hline KS2 & 0.845 & 33.414 & 0.000 & significant \\
\hline KS3 & 0.894 & 52.436 & 0.000 & significant \\
\hline KS4 & 0.909 & 61.454 & 0.000 & significant \\
\hline KS5 & 0.833 & 30.070 & 0.000 & significant \\
\hline
\end{tabular}

Source: Primary data processed, 2021

Based on these data, it appears that there are five indicators in HR Competency. Of the five, the KS4 indicator, namely Supporting the smoothness and accuracy of achieving goals in the Procurement of Goods/Services related to the Understanding factor in HR competence has the highest outer loading value.

2. Outer Model on IEP Innovation Variables

IEP innovation is the second variable that has five indicators in determining its measurement. The results of the outer model are presented in the table below.

Table 5. Outer Model Results on IEP Innovation Variables.

\begin{tabular}{ccccc}
\hline Indicator & Outer Loading & T-statistic & P-value & Information \\
\hline IIEP1 & 0.872 & 19.140 & 0.000 & significant \\
\hline IIEP2 & 0.901 & 63.749 & 0.000 & significant \\
\hline IIEP3 & 0.852 & 23.299 & 0.000 & significant \\
\hline IIEP4 & 0.745 & 6.888 & 0.000 & significant \\
\hline
\end{tabular}




\begin{tabular}{|c|c|c|c|c|}
\hline IIEP5 & 0.813 & 32.643 & 0.000 & significant \\
\hline
\end{tabular}

Based on these data, it appears that there are five indicators in the IEP Innovation variable. Of the five, the IIEP2 indicator, namely the provider can monitor the procurement stages online and more quickly regarding the factor of creative ideas or new methods in innovation with the highest outer loading value.

3. Outer Model on Service Quality Variables

Company performance is the third variable that has eight indicators in determining its measurement. The results of the outer model of the service quality variable are presented in the table below.

Table 6. Outer Model Results on Service Quality Variables

\begin{tabular}{ccccc}
\hline Indicator & Outer Loading & T-statistic & P-value & Information \\
\hline KP1 & 0.825 & 29.058 & 0.000 & significant \\
\hline KP2 & 0.823 & 31.182 & 0.000 & significant \\
\hline KP3 & 0.789 & 24.340 & 0.000 & significant \\
\hline KP4 & 0.850 & 19.917 & 0.000 & significant \\
\hline KP5 & 0.731 & 8.762 & 0.000 & significant \\
\hline KP6 & 0.887 & 32.883 & 0.000 & significant \\
\hline KP7 & 0.762 & 20.274 & 0.000 & significant \\
\hline KP8 & 0.900 & 39.825 & 0.000 & significant
\end{tabular}

Source: Primary data processed, 2021

Based on these results, it appears that there are eight indicators in testing the Company's Performance. Of the eight KP8 indicators, namely Having appropriate skills, Having technological experience with the highest outer loading value.

4. Outer Model on Project Management Variables

The Project Management variable which is the fourth variable in determining the indicators is divided into five. The Outer model of the IEP Innovation Building variable can be seen from the table below.

Table 7. Outer Results of Project Management Variable Model

\begin{tabular}{ccccc}
\hline Indicator & Outer Loading & T-statistic & P-value & Information \\
\hline MP1 & 0.924 & 46.593 & 0.000 & significant \\
\hline MP2 & 0.758 & 7.801 & 0.000 & significant \\
\hline MP3 & 0.858 & 33.895 & 0.000 & significant \\
\hline MP4 & 0.899 & 36.089 & 0.000 & significant
\end{tabular}

Source: Primary data processed, 2021

Based on these data, it appears that there are four indicators in project management. But of the four, the MP1 indicator, namely the time of processing is right and not delayed, even if it is delayed according to the agreed terms, the outer loading value is the highest.

5. Outer Model on Project Performance Variables

Project Performance, which is the fifth variable, determines the indicators that are divided into five. The Outer model of Project Performance is shown in the table below. 
Table 8. Outer Model Results on Project Performance Variables

\begin{tabular}{lllll}
\hline Indicator & Outer Loading & T-statistic & P-value & Information \\
\hline KJ1 & 0.856 & 24.083 & 0.000 & significant \\
\hline KJ2 & 0.903 & 38.408 & 0.000 & significant \\
\hline KJ3 & 0.835 & 23.764 & 0.000 & significant \\
\hline KJ4 & 0.653 & 8.665 & 0.000 & significant \\
\hline
\end{tabular}

Source: Primary data processed, 2021

Based on the test results of the outer model, it appears that the project performance is identified by five indicators. Of the five, it can be seen that the $\mathrm{KJ} 2$ indicator, namely Management is able to optimize the contribution of suppliers, subcontractors with the highest outer loading value.

\section{The Influence of HR Competencies on Project Management}

Testing the direct influence between HR Competence on Project Management obtained the inner weight coefficient with a value of 0.315 following T-statistics of 2.871 and $\mathrm{P}$-value of 0.002 because the T-statistics value $>1.96$. If the $\mathrm{P}$-value $<0.05$, then there is a significant direct influence of HR Competence on Project Management.

HR is a crucial aspect in project implementation. Each individual involved is driven by project management so that they can take on their respective roles as much as possible, can plan as well as possible and are competent in project management. In the scope of national and human development that

integrated, professional competence and mature personal can strengthen each other. A strong attitude and behavior can also be formed through professionalism. HR competence has an effect on project management. Human Resources in Project Management focuses on Project Team recruitment, organization and management until the end of the project. His role starts from defining the core competencies that will be needed, to team building and motivation. The relationship between Human Resource Management and Project Management is strategic. Both are useful for company competitiveness. Human Resources are the key to every job done in the company because they represent the people. Project Management is measured by the success of different projects which can represent any benefit, innovation or improvement. It seems that project success requires success in team project management, which is an HR function. Three main processes are taken into account: selection, training and management. They represent layers of the overall role of Human Resources in Project Management. They are described and analyzed while raising key issues to be addressed.

\section{Influence of IEP Innovation on Project Management}

Testing the direct influence between IEP Innovation on Project Management obtained the inner weight coefficient with a value of 0.482 following T-statistics of 4.125 and P-value of 0.000 because the T-statistics value is $>1.96$. If the $\mathrm{P}$-value $<0.05$, then there is a significant direct effect of IEP Innovation on Project Management.

In line with Maria's (2011) research which examines using systemic project management, which requires providing flexibility in planning, communication, and controlling activities, technological innovation projects are more successful than conventional systems. The technology system provides the flexibility to manage innovation, complexity, and uncertainty in projects more successfully than conventional systems so that it is easier to monitor and track data to create the best quality, price and quality. 
Bendik (2010) and Ahuja et al (2010) state that building project management (Building Project Management) requires effective coordination and collaboration between multiple project team organizations which can be achieved by real-time flow of information between all participants. In the current scenario, this can be achieved with the use of information communication technology (IT). The results of the analysis of Ahuja et al (2010) are helpful in showing that the increased and mature use of IT for general administration in organizations will lead to:

a. Better IT infrastructure within the organization

b. Electronic database development; and

c. Confident staff using information technology (IT) tools

In such a scenario, staff will use advanced software and IT technology for project management (PM) processes and that will lead to increased adoption of IT for PM processes. But, for general administration as well, IT adoption will be enhanced if the organization interacts more with geographically dispersed agencies and senior management feels that significant benefits will be gained by IT adoption. All factors are interrelated and their effects cannot be maximized separately.

Factors that affect project management performance, namely the project life cycle (PLC) and key performance indicators (KPI). The results of Humaidi and Said's (2011) analysis show that these two factors have an influence on project management performance in the field of ICT and construction projects. The T-Test results also show that there is no significant difference between ICT and construction projects in Klang Valley, Malaysia.

Lee, Lee and Yu (2010) stated that the main IT application, project management information system (PMIS) has played an important role in the construction management process. This is because PMIS is an information system that collects, integrates, and disseminates the outputs of the management process Based on the test results of the outer model, it appears that the project performance is identified by five indicators. Of the five, it can be seen that the $\mathrm{KJ} 2$ indicator, namely Management is able to optimize the contribution of suppliers, subcontractors with the highest outer loading value.

\section{The Influence of HR Competencies on Project Management}

Testing the direct influence between HR Competence on Project Management obtained the inner weight coefficient with a value of 0.315 following T-statistics of 2.871 and $\mathrm{P}$-value of 0.002 because the T-statistics value $>1.96$. If the $\mathrm{P}$-value $<0.05$, then there is a significant direct influence of HR Competence on Project Management.

HR is a crucial aspect in project implementation. Each individual involved is driven by project management so that they can take on their respective roles as much as possible, can plan as well as possible and are competent in project management. In the scope of national and human development that integrated, professional competence and mature personal can strengthen each other. A strong attitude and behavior can also be formed through professionalism. HR competence has an effect on project management. Human Resources in Project Management focuses on Project Team recruitment, organization and management until the end of the project. His role starts from defining the core competencies that will be needed, to team building and motivation. The relationship between Human Resource Management and Project Management is strategic. Both are useful for company competitiveness. Human Resources are the key to every job done in the company because they represent the people. Project Management is measured by the success of different projects which can represent any benefit, innovation or improvement. It seems that project success requires success in team project management, which is an HR function. Three main processes are taken into account: selection, training 
and management. They represent layers of the overall role of Human Resources in Project Management. They are described and analyzed while raising key issues to be addressed.

\section{Influence of IEP Innovation on Project Management}

Testing the direct influence between IEP Innovation on Project Management obtained the inner weight coefficient with a value of 0.482 following T-statistics of 4.125 and $\mathrm{P}$-value of 0.000 because the T-statistics value is $>1.96$. If the $\mathrm{P}$-value $<0.05$, then there is a significant direct effect of IEP Innovation on Project Management.

In line with Maria's (2011) research which examines using systemic project management, which requires providing flexibility in planning, communication, and controlling activities, technological innovation projects are more successful than conventional systems. The technology system provides the flexibility to manage innovation, complexity, and uncertainty in projects more successfully than conventional systems so that it is easier to monitor and track data to create the best quality, price and quality.

Bendik (2010) and Ahuja et al (2010) state that building project management (Building Project Management) requires effective coordination and collaboration between multiple project team organizations which can be achieved by real-time flow of information between all participants. In the current scenario, this can be achieved with the use of information communication technology (IT). The results of the analysis of Ahuja et al (2010) are helpful in showing that the increased and mature use of IT for general administration in organizations will lead to:

a. Better IT infrastructure within the organization

b. Electronic database development; and

c. Confident staff using information technology (IT) tools

In such a scenario, staff will use advanced software and IT technology for project management (PM) processes and that will lead to increased adoption of IT for PM processes. But, for general administration as well, IT adoption will be enhanced if the organization interacts more with geographically dispersed agencies and senior management feels that significant benefits will be gained by IT adoption. All factors are interrelated and their effects cannot be maximized separately.

Factors that affect project management performance, namely the project life cycle (PLC) and key performance indicators (KPI). The results of Humaidi and Said's (2011) analysis show that these two factors have an influence on project management performance in the field of ICT and construction projects. The T-Test results also show that there is no significant difference between ICT and construction projects in Klang Valley, Malaysia.

Lee, Lee and Yu (2010) stated that the main IT application, project management information system (PMIS) has played an important role in the construction management process. This is because PMIS is an information system that collects, integrates, and disseminates the outputs of the management process.

\section{CONCLUSION}

Based on the analysis and discussion, it is concluded that HR Competence towards Project Management is obtained by the inner weight coefficient with a value of 0.315 following T-statistics of 2.871 and P-value of 0.002 because the T-statistics value is > 1.96. If the P-value $<0.05$, then there is a significant direct influence of HR Competence on Project Management. HR is a crucial aspect in project implementation. Each individual involved is driven by project management so that they can take on their 
respective roles to the maximum extent possible. HR competence has an effect on project management. The relationship between Human Resource Management and Project Management is strategic. Both are useful for company competitiveness. Human Resources are the key to every job done in the company because they represent the people. Project Management is measured by the success of different projects that can represent benefits, innovation, costs, quality, and lead time. It seems that project success requires success in team project management, which is an HR function.

\section{REFERENCES}

Adyatma, Erdi, \& Oktaviani, Rachmawati Meita. (2015). Pengaruh pendapatan asli daerah dan dana alokasi umum terhadap belanja modal dengan pertumbuhan ekonomi sebagai pemoderasi. Dinamika Akuntansi Keuangan Dan Perbankan, $4(2)$.

Endratno, Hermin. (2013). Talent management dalam meningkatkan kinerja organisasi. Sustainable Competitive Advantage (SCA), 1(1).

Fernandes, Adji Achmad Rinaldo. (2017). Metode Statistika Multivariat Pemodelan Persamaan Struktural (SEM) Pendekatan WarpPLS. Malang: Universitas Brawijaya Press.

Fitrah, Muh. (2018). Metodologi penelitian: penelitian kualitatif, tindakan kelas \& studi kasus. Sukabumi: CV Jejak (Jejak Publisher).

Harahap, Lenni Khotimah, \& Pd, M. (2018). Analisis SEM (Structural Equation Modelling) dengan Smartpls (partial least square). Makalah Ilmiah Tidak Diterbitkan. Semarang: Fakultas Sains Dan Teknologi UIN [Universitas Islam Negeri] Walisongo. Tersedia Secara Online Juga Di: Http://Fst. Walisongo. Ac. Id/Wp-Content/Uploads/2020/06/Artikel_Lenni-Khotimah-Harahap.

Kurniawan, Paulus, \& Budhi, Made Kembar Sri. (2017). Smart Leadership-Being a Decision Maker\# 2. Yogyakarta: Penerbit Andi.

Naleng, Adrian Yoro, \& Monintja, Donald K. (2020). Moving forward ODSK. Makassar: Nas Media Pustaka.

Noferi, Syafran, \& Wibowo, Andreas. (2017). Analisis Faktor Penyebab Calon Penyedia Jasa Melakukan Pendaftaran Lelang Tetapi Tidak Melanjutkan Memasukan Dokumen Penawaran pada Pengadaan Jasa Konstruksi Pemerintah.

Normasari, Selvy. (2013). Pengaruh Kualitas Pelayanan Terhadap Kepuasan Pelanggan, Citra Perusahaan Dan Loyalitas Pelanggan Survei Padatamu Pelanggan Yang Menginap Di Hotel Pelangi Malang. Jurnal Administrasi Bisnis, 6(2).

Pujiono, B. (2017). Konsep Manajemen Proyek. Last Modified.

Raharja, Erky. (2014). Aspek Perpajakan Atas Jasa Konstruksi Guna Pemenuhan Kewajiban Perpajakan Di PT Tiga Muara Jaya Surabaya. Surabaya: STIE Perbanas Surabaya.

Reagan, Henri Asri. (2016). Analisis Pengaruh Pertumbuhan Ekonomi terhadap Dimensi Pembangunan Manusia dengan Menggunakan Response Based Unit Segmentation In Partial Least Square (REBUS PLS). Surabaya: Institut Teknologi Sepuluh Nopember. 
Setiawan, Ahmad Budi. (2017). Kebijakan Teknologi Informasi dan Komunikasi Untuk Mendorong Pembentukan Model Bisnis Masa Depan Policy of Information and Communication Technologies to Promote the Formation of Future Business Models. Jurnal Pekommas, 2(2), 193-204.

Siswanto, Adil, \& Alfian, Alfan. (2016). Program dan Proyek Strategis Pembangunan Desa. Jakarta Pusat: Mata Garuda Institute Press.

Ulfah, Fitriana, \& Rahardjo, Susilo Toto. (2013). Analisis Pengaruh Implementasi Manajemen Kualitas Terhadap Kinerja Organisasi Pada Usaha Kecil Menengah (UKM) di Kota Salatiga. Fakultas Ekonomika dan Bisnis. 